\title{
VIRTUAL SPHERE: A SITE TO NEGOTIATE THE IMAGE OF LENGGER BANYUMAS
}

\author{
Lynda Susana Widya Ayu Fatmawaty'; Condro Nur Alim²
}

${ }^{1}$ English Department, Humanities Faculty, Univeritas Jenderal Soedirman

Jl. dr. Soeparno Utara No. 1, Grendeng, Purwokerto 53122, Indonesia

${ }^{2}$ Faculty of Letters, Universitas Muhammadiyah Purwokerto

Jl. KH. Ahmad Dahlan, Dusun III, Dukuhwaluh, Banyumas, Jawa Tengah 53182, Indonesia

1'lyndafatmawaty@gmail.com; ${ }^{2}$ condronuralim@ump.ac.id

Received: $01^{\text {st }}$ December 2020/Revised: $24^{\text {th }}$ January 2021/Accepted: $25^{\text {th }}$ January 2021

How to Cite: Fatmawaty, L. S. W. A. \& Alim, C. N. (2020). Virtual sphere: A site to negotiate the image

of Lengger Banyumas. Lingua Cultura, 14(2), 261-266.

https://doi.org/10.21512/lc.v14i2.6837

\begin{abstract}
The research aimed at investigating how Lengger used the virtual sphere to negotiate their image to society. Lengger Banyumas was always stereotyped with the discourse of Queer, Gay, Bisexual, and Transgender (QGBT). Therefore, it led to gender discrimination, not only on the stage but also in their daily life. Consequently, in this 4.0 era, Lengger needed to use social media in order to create a different image as an alternative way to negotiate the dancer's gender identity. The method applied was Hine's virtual ethnography method by applying Habermas theory. Respondents were interviewed virtually through video conference. Meanwhile, the data were collected through their Instagram. The results show that Lengger constructs their image on social media to produce an image by performing double-identity; they are feminine on the stage and masculine in real life. The first identity is a feminine dancer to reveal the image of a professional drag dancer from Banyumas. However, Lengger elaborates the masculine identity in their dance performance by wearing the attribute of female dancers. Meanwhile, Lengger also reveals masculine identity in their real life. As identity is fluid, it indicates that the image will also never be fixed. Thus, this image is reproduced constantly in the virtual sphere as a negotiation towards society's stereotyping.
\end{abstract}

Keywords: virtual sphere, binary gender stereotype, image negotiation, Lengger Banyumas

\section{INTRODUCTION}

In the 4.0 era, the development of social media has become an unavoidable phenomenon. Besides its function to show a self-existence, it is also powerful to construct identity. Thus, this shifting trend might create a new identity through the representation of the image. Social media creates a sphere as space for their users to create freedom in order to express their identity accessibly. Mazali (2011) has stated that individuals or groups 'perform' using the network as a space where identity is created and where they perform or act. Therefore, this site is regarded as a public sphere. Formerly, Habermas (in Kruse, Norris, \& Flinchum, 2018) has stated that the term 'public sphere' is initially constructed through the freedom of individuals to speak publicly, where the public is firstly interpreted as in public space or public place. However, as time goes by, the terms public and space have a broader meaning. It is not seen on the physical aspect anymore but on the construction of the realm entity. Thus, the sphere is possibly constructed by the society as a means of resistance.

One of the iconic performers from Banyumas regency called Lengger, also uses social media to reproduce its image. Lengger, known as Banyumas traditional dance, uses Instagram as a media to negotiate their image on this online platform. This phenomenon is relevant to Pepe's (2020) statement that digital media such as Youtube, Facebook, Instagram, and Twitter have become important spaces for queer people and other minorities to negotiate their identities in recent years. Moreover, the pandemic situation of COVID-19 leads them to even be more creative in 
using social media as a platform of communication. Social media is the site where users construct their image. Further, Mazali (2011) has stated that a person or group may 'perform' their identity while using social media. As identity is constructed by social conditions, social media plays an important role in constructing and representing their identity. In the research, social media is seen as media that can be used in depicting the issues on how Lengger represented their image through this platform. The use of social media enables the subject (Lengger) to construct the new culture actively. Henry Jenkins (in Mazali, 2011) has explained there are four kinds of participatory culture; they are affiliation (Friendster, Facebook, metagaming, game clans, or MySpace), expressions (digital sampling, fan video-making, fan-fiction writing), collaborative problem-solving (Wikipedia, alternative reality gaming, spoiling), and circulation (podcasting and blogging). This participatory culture will also be used to identify Lengger, who has managed to use social media to negotiate their identity.

Based on its history, Lengger is a performance of grateful expressions for the harvest, or it is usually called a baritan ceremony. Lengger is derived from the word leng and ngger that is presumed as leng (hole), a symbol of a woman, but it turns out to be jengger (cock's head) symbolizes a man. Thus, Lengger is defined as a traditional dance performed by a male in female attributes. As Pigeud (in Fatmawaty et al., 2018) has stated that there is Lengger in Banyumas, a traditional dance that is performed in the form of transvestite. However, societies usually associate Lengger with a woman. In fact, there are two different terminologies used to define Lengger. Lengger, which is performed by men, is called Lengger, while Lengger, which is performed by a woman, is called Ronggeng. Unfortunately, both Lengger and Ronggeng are stereotyped negatively by society. Ronggeng is presumed to be sexually associated with a prostitute, while Lengger is typically associated with sexual perversion due to gender bias. Therefore, Lengger has been marginalized by the society's view that leads to 'othering' since they are considered deviant. In some cases, it triggers some Lengger dancers to stop being a dancer because they cannot bear the society's stigma.

The complexity of Lengger intertwines with the emergence of a complicated problem which goes along with its existence nowadays. The main problem faced by Lengger is related to society's negative stigma because of their gender bias in their dancing performance. Further, Claire (2017) has argued that gender bias in dance becomes the main problem that leads to society's stigma. Thus, gender bias in traditional art was identified a long time ago in Indonesia and other parts of the world. In Nordic, for example, men dancers have to wear a woman costume and play a role as a woman in their folk dance, philocoros (Hoppu, 2014). In Indonesia, this kind of art also exists in most regions such as gandrung Banyuwangi, tledhek from East Java, and Lengger from Banyumas. There have been some researches about drag dancers or men dancers who perform themselves as women. Levitt et al. (2018) have investigated how drag performers negotiate with society's stigma about QGBT (Queer, Gay, Bisexual, and Transgender). Levitt et al. (2018) show how those performers are then categorized into high or low status in their research. Although Levitt's research also addresses the issue of 'othering', but this research does not explore the way how the drag dancers cope with that problem. Meanwhile, the research focuses on how Lengger deals with the negative stigma from society. Therefore, it is aimed at probing the way Lengger Banyumas negotiate their identity.

\section{METHODS}

The research uses Lengger Banyumas' Instagram as the object of analysis by applying the virtual ethnography method. Virtual ethnography becomes a new method that elaborates the ethnographic tradition as an embodied research instrument to the internet's social spaces (Hine in Carter, 2018). This method opens the elaboration of the online and offline model widely. As coined by Hallet and Barber (2014) and Hine (in Airoldi, 2018), digital ethnographers have constructed and explored multi-sited fields by investigating both online and offline sites. Further, Hine (in Nasrullah, 2018) has stated that there are two approaches in seeing the phenomenon in cyberspace called 'culture' and as 'cultural artefact'. If this space is considered a culture, then cyberspace will only be used to transfer the message or text. However, cyberspace can change into a cultural artifact in its development, which involved social phenomenon and is produced by the users' social interaction.

Virtual ethnography is used to describe the image of Lengger Banyumas through virtual space. Virtual ethnography is applied in exploring the internet and observing the users, in this case, is Instagram. The aim of elaborating ethnography and the internet is to investigate how the status of the internet is negotiated with the local context of its user (Hine in Zhongxuan, 2018). This shows the communication which is seen through the internet. This method is used to reveal the reality or apparent social phenomenon as well as to reveal what is not related to the users of cyberspace (Nasrullah, 2018). Further, an interview with Lengger Banyumas dancers is conducted in order to provide data. This is in line with what Hine and Corell (in Nasrullah, 2018) have explained that in conducting virtual research, the research can use immediate contact with the research subject or by email, Instagram, Whatsapp, or Skype in order to get the authentic data.

\section{RESULTS AND DISCUSSIONS}

Some scholars may identify Lengger as a traditional drag dance. The existence of Lengger is identified as plausibly paradoxical because in one hand 
they are reified as an artist who preserves the traditional culture, but on the other hand, they are queering. Lengger, a female dance from Banyumas performed by male dancers, perceived society's negative stigma, which is fundamentally constructed by the binary gender attributes. Thus, this binary gender ideology divides the system into femininity and masculinity. This division pertains to the normative gender role in the life of the dancers. Further, the stigma is continuously raised as they are also associated with sexuality. Some dancers probably face similar problems of the negative stereotyping that deals with the issue of gender, class, and sexuality. This is in line with Tobin (in Morad, 2016), who has stated that "in this tango world, gender, sexuality, class, and nationality intersect to produce a masculinity that many observers find troublesome". Accordingly, dancers believe that they need to counter all of the negative stigma. They need media to express their struggle and challenge as well as the exercise of power towards them. Social media then plays its role in democratic freedom by allowing the creation of a sphere for the community.

Social media is identified as an alternative way to articulate the image of Lengger. Realizing the power of social media in exposing the image, the dancers also use social media platforms in dealing with the negative stigma from society. Lengger tries to explore their dance through Instagram to produce their image. Instagram then becomes the media to present their identity and to produce their narratives. In this case, identity is constructed as a set of narratives about Lengger's life. This presentation and labeling deal with the origin and destiny associated with strategies and identification (Anthias in Kassaye, Ashur, \& van Heelsum, 2016). Moreover, during the pandemic of COVID-19, there has been a great impact for Lengger as they cannot perform in public spaces. Thus, it triggers them to be more active in using social media. So far, social media has attracted the public not only as an arena to reveal their existence but also as an alternative media of resistance. Instagram features enable displaying a video up to 60 seconds, some characters of text, and lots of space for displaying photos or videos. These Instagram features attract Lengger to use this platform because of some practical benefits the Lengger may receive. In relation to participatory culture, Instagram as one of the social media platforms can be categorized as an affiliation associated with Friendster or Facebook. This eases the users to deliberately use it for certain reasons. The societies' negative stigma towards Lengger dancers is a challenge for Lengger to deal it through smart negotiations.

Lengger is widely spread in Banyumas region, including in some neighboring cities such as Banjarnegara, Cilacap, Kebumen, and Purbalingga. These regions also have Lengger communities; one of them is Langgeng Sari, located in Baturraden. This community is managed by Tora Dinata. Another Lengger community in Banyumas is Rumah Lengger, located in Banyumas and is led by Rianto. However, not all Lengger dancers join such communities since some of them choose to perform individually. Some Lengger have chosen an individual career, among others are Agnes (whose real name is Agus Widodo) and Aan. These Lengger produce their self-image through Instagram by showing both their feminine and masculine sides. Some of them purposely negotiate the stigma through their dance creation by elaborating on male and female attributes. Indeed, it is aimed at emphasizing the existence of Lengger as a professional dancer. Lengger dancers also represent their daily lives as husbands and other masculine values which ratify their existence as males.

Dealing with the negative image of Lengger, some of them realize that being a part of a Lengger community is much easier for them to negotiate with the negative stigma from society. In a virtual interview with Anggun, one of Langgeng Sari Lengger community members, it is found that Lengger has a big burden because of society's stigma that the dancers have a non-normative sexual orientation. The stigma is constructed by society as they questioned Lengger's identity. Indeed, this phenomenon is also highlighted by Butler (in Murtagh, 2017) that the in-betweenness leads to the questioning of gender identity. Therefore, this condition threatens their life as well as the existence of Lengger. Consequently, they are being marginalized not only by society but also by their family and friends. Jost and Banji (in Khalil, 2019) have argued that stereotypes are used to justify social and power relations in society, in which it also attempts negative self-stereotyping. Thus, Tora, Lengger's manager, admits that they must choose a media to negotiate the stereotyping by using Instagram. Lengger's awareness towards this condition is stated as 'situated knowers' that some theories coined in term of marginalized groups, who understand the social positions in power relation experienced by them (Collins in de Vries, 2015). However, Instagram is chosen by this group as a site to articulate their self-image as well as to promote Lengger. As professional dancers, Lengger try to elaborate the story in their dance movement that reveals their femininity and masculinity in one body as well as their negotiation as a cross-dresser. Furthermore, they also reveal their daily life to affirm that Lengger has a normal life under heteronormativity to emphasize that they do not belong to homosexuality. The strategy of resistance by modifying dance and festival has been globally used. Celeste (2017) have stated that Manobo communities have used their performance due to their experience of being exiled from their traditional land. Indeed, it leads them to recreate new meaning in which they construct their existence, adapting into the world as well as celebrating the heritage. Therefore, festivals and performance are used as the opportunity to construct the image in a way that they manage the resistance.

In the context of cultural production, Lengger uses their agency power to create a new culture in a particular discourse. Lliane Loots has stated in Titley (2012) that cultural production allows social subjects agency a chance to speak and create a new discourse. 
This means that the main reason for using social media is to create a sphere that reveals the resistance, as it is expected to produce new discourse both virtually and in reality. Tora and Rianto smartly manage the caption of their posting image on Instagram to ensure their position as the cultural preservation. The hashtags that they frequently used are, among others, \#Lengger, \#Lenggerbanyumasan, \#budaya, \#budayaindonesia, and \#indonesia. This is intentionally created to let the followers easily recognize that they are a professional dancer. Lengger dancers are transforming themselves as celebrities. Whannel (in Turner, 2014) has stated that celebrities are now increasingly exploring ways to control self-representation. This is in line with the media production industry that enables people to find new strategies to control the image they produce. It cannot be denied that Lengger dancers have become celebrities.

Thus, during the pandemic of COVID-19, Rianto, a professional Lengger dancer who lives in Japan, even creates Lengger's challenge by inviting all of his followers to practice by performing a Lengger dance. Rianto, in this case, takes some different modes of negotiation. He combines Instagram and Youtube as a site to renegotiate his existence. While he gets some benefits from being the artist of Garin's Kuсumbu Tubuh Indahku (2018), which won some medals, Rianto successively negotiates Lengger's existence. By broadcasting Lengger's activities on Instagram and Youtube, he deliberately lets his followers join a challenge. In one of his videos, he performs the dance by wearing a casual outfit as a male; further, he posts his dance by wearing Lengger custom. Rianto, who has more than thirteen thousand followers, leads these challenges to shape a new culture in this pandemic situation. This phenomenon is in line with Habermas' idea (Jin, 2017) that the public sphere's logic is independent of economic and political power. Thus, he continuously advises people to stay at home but to be productive, with the hashtag \#challengeriantoLengger, \#bahagiadirumah, \#Lenggerbanyumas, \#covid19. These hashtags are the creation of Lengger to establish their existence in the virtual sphere.

One of the most notable results of a virtual interview with Lengger Langgengsari communities is that the fact that they elaborate characters of masculine and feminine in their dance creation. In terms of costumes, it is clear that the attributes used by the Lengger are the same as the attributes used by the female Lengger, such as jarit, kebaya, beautiful makeup, sampur, bun, and other women's accessories. The dancer's body shape is also equipped with foam to replace the chest and hips to make it fuller and resembles the real woman. This is done to bear the nuances of women who support their appearance on the stage. Fortunately, this embodied feminity is not only manifested in the range of movements created in their dancing but also through gestures and other feminine attributes. They usually start with the plot of a male dancer who got indang (the spirit of Lengger). This indang then turns the male dancers into women dancers, with beautiful makeup and costume. At the end of this dance, the dancers open the bun to symbolize a solid relationship between the dancer and the image they want to create. In line with Gabler's theory, the process of removing the bun is part of the affirmation of gender. This is one of the negotiations made by the Langgengsari community group. In terms of transgenderism, there is a concept of 'unveiling 'or 'dewigging'. This concept is stated by Gabler (Murtagh, 2013) in the situation that the wig is the main marker of the impersonation of a woman. In the case of the wig, it is an attempt to show the actual gender of the binary opposition between men and women. In Indonesian society, this wig concept can also be replaced with a bun as Javanese women's accessories that show the characteristics of a woman. In the concept of art produced by Lengger Langgengsari, dance creations bring the concept of men who become women dancers.

Besides its function as a platform to express resistance, social media also becomes a site to produce the identity to be performed. Indeed, Lengger dancers use social media not only to create their sphere but also to negotiate with the stigma. A Lengger dancer from Binangun, a district in Banyumas regency, Agus Widodo or known as Agnes, admits that through Instagram, he experiences much progress in his career as a Lengger dancer. Furthermore, Agnes states that he also often receives gender discrimination. His existence as a man who performs a woman's dance with all his attributes causes him to be the target of 'bullying'. Thus, social media also has become one of his alternatives to create his identity. Whannel (in Turner, 2014) argues while celebrities themselves are increasingly exploring ways of controlling their own representations. Some of the media production industries have found new and effective strategies for controlling the images they produce. The identity, therefore, is constructed continuously. This identity construction has turned Agnes to be recognized widely by society. He gets the status of a celebrity as the result of the identity construction through social media. The discourse of the New Order era that represses the society to live under heteronormativity prevents the freedom of expression. Unfortunately, the marginalization towards Lengger lasts up to this reformation era. Another surprising fact is that in this reformation era, Agnes is required to appear as a male when performing on TVRI, a stateowned TV station, as the TV rules that Agnes must appear without a gender bias. He has to present his self-identity in a heteronomative patron. He is not allowed to wear a woman costume because it leads to the judgment closely associated with LGBT (Lesbian, Gay, Bisexual, and Transgender). Thus, Agnes also decides to use social media as a platform that enables him to show more democratic acceptance towards his profession. Further, Agnes has great achievements in his career. Agnes expertise as a Lengger dancer, Sinden, drummer, and wedding MUA enables him to challenge the community's discrimination.

The way of challenging society's negative stigma 
is also done by the dancers by publicly showing their family life on social media. Rianto proudly depicts his happy marriage with a Japanese woman by showing some beautiful scenes of Japan and some activities with his wife. Further, in a Youtube channel, Tora also reveals his life with his family and his daughter. At the same time, Agnes and other Lengger reveal their male identity before wearing the female costume. Indeed, it is assumed that this is done as other modes of resistance by reinforcing their normal life under the heteronormative norms.

\section{CONCLUSIONS}

The research investigates both Lengger as a culture and a reconstruction process of identity experienced by the Lengger. This process is a mode of negotiation towards the negative stigma of the society towards them. The research shows that Lengger Banyumas has used social media such as Instagram as a sphere to negotiate their identity. The identity is revealed under the construction of a binary gender system. The construction of performative identity gives a clear depiction of how Lengger's identity is constructed through their performance.

Lengger uses social media as a new sphere to strengthen their existence to deal with gender discrimination as well as to express their identity. Lengger's identity is expressed through the demonstration of Lengger's masculinity in their daily life. On Instagram and Youtube channels, some of the Lengger dancers present their family, children, and wives to reveal their identity. It is expected that by demonstrating themselves as a father or a husband, it would give them a chance to produce the masculine identity. They are living in the relationship under the heteronormativity rules. Thus, Lengger negotiates identity through the sphere to express their identity. This identity negotiation informs society that Lengger dancers are not cross-gender, but they are crossdressers. Lengger vigorously produces their image within the virtual sphere such as Instagram and Youtube, as well as boosting themselves as a celebrity.

\section{REFERENCES}

Airoldi, M. (2018). Ethnography and the digital fields of social media. International Journal of Social Research Methodology, 21(6), 661-673. https://doi. org/10.1080/13645579.2018.1465622.

Carter, P. (2015). Virtual ethnography: Placing emotional geographies via YouTube. In Social Memory and Heritage Tourism Methodologies (pp. 4867). UK: Taylor and Francis Inc. https://doi. org/10.4324/9781315797915.

Celeste, B. L. D. (2017). Dancing amidst displacement: Binanog dance as cultural adaptation and resistance. Philippine Sociological Review, 65, 97-120.

Claire, E. (2017). Dance studies, gender, and the question of history. Women, Gender, History, 46(2), 157-185. https://doi.org/10.4000/clio.13826.

de Vries, K. M. (2015). Transgender people of color at the center: Conceptualizing a new intersectional model. Ethnicities, 15(1), 3-27. https://doi. org/10.1177/1468796814547058.

Fatmawaty, L. S. W. A., \& Marahayu, N. M. Utami, S. M. B., \& Suhardi I. (2018). Lengger lanang langgeng sari dalam pertunjukan seni di Banyumas: Perspektif Bourdieu (The interrelated pattern of lengger lanang langgeng sari existence in Banyumas art performance: Bourdieu's Perspective. Jentera: Jurnal Kajian Sastra, 7(2), 198-214. https://doi. org/10.26499/jentera.v7i2.916.

Hallet, R., \& Barber, K. (2014). Ethnographic research in cyber era. Journal of Contemporary Ethnography, 43(3), 306-330. https://doi. org/10.1177\%2F0891241613497749.

Hoppu, P. (2014). Folk dancers cross-dressed: Performing gender in the early nordic folk dance movement. Journal of Folklore Research, 51(3), 311-335. https://doi.org/10.1353/jfr.2014.0014.

Jin, D. Y. (2017). Understanding civic engagement in the smartphone era: Corporate sphere vs. public sphere. Development and Society, 45(2), 353-378. http://doi. org/10.21588/dns/2016.45.2.008.

Kassaye, A., Ashur, I., \& van Heelsum, A. (2016). The relationship between media discourses and experiences of belonging: Dutch Somali perspectives. Ethnicities, 16(6), 773-797. https://doi. org/10.1177/1468796816653627.

Khalil, M. (2019). Stereotyping and power relations a phenomenological reflection. Reflective Practice, 20(6), 679-691. https://doi.org/10.1080/14623943.2 019.1693356.

Kruse, L. M., Norris, D. R., \& Flinchum, J. R. (2018). Social media as a public sphere? Politics on social media. Sociological Quarterly, 59(1), 62-84. https:// doi.org/10.1080/00380253.2017.1383143.

Levitt, H. M., Surace, F. I., Wheeler, E. E., Maki, E., Alcántara, D., Cadet, M., Cullipher, S., Desai, S., Sada, G. G., Hite, J., Kosterina, E., Krill, S., Lui, C., Manove, E., Martin, R. J., \& Ngai, C. (2018). Drag gender: Experiences of gender for gay and queer men who perform drag. Sex Roles, 78, 367-384. https:// doi.org/10.1007/s11199-017-0802-7.

Mazali, T. (2011). Social media as a new public sphere. The MIT Press Journals, 44(3), 290-291. https://doi. org/10.1162/LEON_a_00195.

Morad, M. (2016). Queering the macho grip transgressing and subverting gender in Latino music and dance. Dans Ethnologie Francaise, 46(1), 103-114. https:// doi.org/10.3917/ethn.161.0103.

Murtagh, B. (2013). Genders and sexualities in Indonesian cinema: Constructing gay, lesbi, and waria identities on screen. London: Routledge.

Murtagh, B. (2017). Double identities in Dorce's comedies: Negotiating gender and class in New Order Indonesian cinema. Journal of Humanities and Social Sciences of Southeast Asian, 173(2-3), 181207. https://doi.org/10.1163/22134379-17302021. 
Nasrullah, R. (2018). Etnografi virtual: Riset komunikasi, budaya, dan sosioteknologi di internet. Bandung: Simbiosa Rekatama Media.

Pepe, P. P. (2020). Body of resistance: Blackness and the politics of (in)visibility on YouTube. Bulletin of Spanish Studies, 97(7), 1187-1210. https://doi.org/1 $0.1080 / 14753820.2020 .1815983$.

Titley, G. (2012). Re-situating culture in the body politic. Retrieved from https://pjp-eu.coe.int/ documents/42128013/47261677/2004_resituating_ culture_coepub.pdf/7d5401b2-4954-4049-b765de001d $\overline{2} 6 \mathrm{f} 30 \mathrm{~d}$.

Turner, G. (2014). Understanding celebrity. London: SAGE Pub.

Zhongxuan, L. (2018). Paradoxical empowerment and exploitation: Virtual ethnography on internet immaterial labour in Macao. Journal of Creative Communications, 13(1), 1-16. https://doi. org/10.1177/0973258617743618. 